\title{
The Effect of Political Socialization through Opinion Leader toward Political Participation of Borderline Citizens in 2019 General Election (Raihat-Atambua District Border District)
}

\author{
Wida Nofiasari ${ }^{1}$, Ahmad Mulyana $^{2}$, Henni Gusfa ${ }^{3}$ \\ \{wnofiasari@gmail.com ${ }^{1}$, ahmadmulyana09@gmail.com², henni.gusfa@gmail.com³ \\ Universitas Mercu Buana, Indonesia ${ }^{1,2,3}$
}

\begin{abstract}
In socializing politics in border region is quite difficult, the limitations of media entering the border areas and the limitations in the use of Indonesian have the public struggle to obtain information about the election. This condition is getting worse with the unstable internal political upheaval in the border region. Therefore, it takes the presence of an opinion leader figure to bridge the information gap between outsiders and rural. The purpose of this study was to determine the effect of political socialization in the election process through opinion leaders on community participation in the border region of the Republic of Indonesia-Timor Leste, Raihat District, NTT in the 2019 elections. This research was a quantitative study using an explanatory approach. The results of the research that have been done show that political socialization, through opinion leaders has a significant influence on political participation.
\end{abstract}

Keywords: Political Socialization, Opinion Leader, Political Participation.

\section{Introduction}

On April 17, 2019, Indonesia held a General Election of Members of the House of Representative, Leadership of Political Party at Provincial, Assembly at Provincial and the Presidential Election simultaneously. Based on data from the General Election Commission, candidates who fought in the 2019 elections were 7,968 candidates for the House of Representative, 807 for Leadership of Political Party at Provincial, and two pairs of presidential candidates, namely Joko Widodo-K.H. Ma'ruf Amin and Prabowo SubiantoSandiaga Salahuddin Uno. In the success of the election, the public needed adequate information so that the public could participate in the election, such as information about the permanent voter list to ascertain whether or not it had been registered as a condition for voting on Election Day as well as information about the rules in the electoral process. Therefore, political socialization was needed by the election organizers as a flow of information about the rules in the electoral process.

Political socialization in the election is very important to support the success of the election itself, especially to suppress abstentions. In actualizing the ideals of social fairness or justice, effectiveness in political socialization requires an appropriate communication model to provide information about elections. Rogers in his book (Prof. Dr. Hafied Cangara, M.Sc 1998: 20) explains about this requirement in which communication is a relationship with the 
existence of an exchange of information (message) where it aspires a change in attitude and behavior and togetherness in creating mutual understanding of the people participating in a communication process. For that reason, effective communication is needed to provide information that is easily understood so that political participation can be increased.

But the phenomenon that was often encountered in socializing politics in border areas was that its community had a tendency in society where citizens would often communicate with each other by choosing a "not too high" level of education. Another uniqueness was that they did not really master Indonesian well compared to their region or mother language that was commonly used in daily life. The limitations of the media entering the border region made it difficult for them to obtain information about the election. In addition, with all internal political unstable upheaval in the border region, the security condition at the border could be considered vulnerable.

Raihat District has a strategic value in the Belu Regency because it is located directly adjacent to the Democratic Republic of Timor Leste. Because of its location, Raihat is seen as an area that can contribute more, in this development movement.

Data from the General Election Commission (GEC) announced at kpu.go.id page showed voter participation in border areas tended to decrease. In Nunukan Regency, North Kalimantan Province, for example, voter participation in the 2014 election was only 62.35 percent and in the 2015 elections, it simultaneously decreased to 60 percent. Likewise, voter participation in Belu Regency, East Nusa Tenggara Province declined from 74 percent in the 2014 elections to 64.5 percent in the 2018 local elections. This was where in the cultural perspective of previous rural community was still very taboo with the name "politics" but with technological advances, it could be reduced. For this reason, in order to convince people in rural areas, they necessarily needed someone they trusted about the development issues. One political actor who had good credibility became opinion leader. This was where the presence of the opinion leader figure was needed to bridge the information gap between outsiders and rural communities. Although it was not yet optimal, opinion leaders were people who were now believed to be the starting point and axis for the local community. In the research on opinion leaders conducted by Weimann et al [1] entitled "Looking For Opinion Leaders: Traditional Vs. Modern Measures In Traditional Societies", published in the International Journal of Public Opinion Research Vol. 02 No. 19, it concluded its role's influence and operationalization in social settings. The researchers could show that modern scales such as the PS scale was applied in modern societies while traditional methods (socio-metric mapping, informant reports) were more efficient in traditional societies.

From the phenomena above, the purpose of this study was to influence the political socialization of the election process through opinion leaders on community participation in the border region of the Republic of Indonesia-Timor Leste, Raihat District, NTT in the 2019 elections.

\section{Theoretical Review}

\subsection{Communication}

Communication is the whole process used to reach the thoughts of others. Communication can take the form of verbal, visual, or a combination of both. In a feedback, communication is expected to be able to achieve the intended purpose in communicating. In 
this research, the communication theory used was Two Step Flow Communication theory, which can be translated into two-stages, is a kind of communication theory explaining how the process of receiving information from the mass media does not directly reach the public. Instead the data seems to indicate "that ideas often flow from radio and print to opinion leaders and from these to the less active sections of the population" [2]. Information conveyed through radio and print media is received by opinion leaders and then passed on to the general public. The two-stage communication model can help to place attention on the role of the mass media associated with interpersonal communication and view the masses as individuals who actively interact.

\subsection{Political Socialization}

Political socialization is the process by which individuals are able to receive knowledge, values, and attitudes towards the political system of their society. This political socialization is an important part in a political system because with political socialization, an individual can learn politics either consciously or unconsciously. According to Efriza [3], political socialization is part of a social process. Socialization is a continuous teaching and educational activity taken place or carried out by individuals or groups to other individuals or groups.

Based on the explanation above, what it means by political socialization in this research is the process by which a person can find out political knowledge from his environment that is obtained from other individuals or groups either consciously or unconsciously. Especially, it occurs when a person has not reached maturity which trigger a certain political attitude and orientation in relation to the ongoing political life.

\subsection{Opinion Leader}

Opinion Leader (opinion leaders) is a concept that is familiar to public relations activities. Literally, the concept of opinion leaders is addressed to opinion leaders or those who have formally influenced in society. Based on the understanding in the perspective of communication sociology, opinion leaders are described as figures that have influenced, and are socio-economically different from other communities. In addition, they also have a high interest in the developing issues; more informative in presenting issues than ordinary people.

According to Kotler and Keller [4], opinion leaders are people in informal communication who deal with products and offer advice or information about certain products or their categories. According to Burt [5], opinion leaders can be described as people, through personal interaction, who are able to make ideas or innovations and share them with people that communicate with them. According to Yukl [6] opinion leaders have characteristics, namely high energy levels and tolerance to pressure, self-confidence, internal control centers, emotional stability and maturity, personal integrity, and power motivation.

\subsection{Political Participation}

According to Surbakti [7], political participation is the participation of ordinary citizens in determining all decisions concerning or influencing their lives. In accordance with the term political participation, it means the participation of ordinary citizens who do not have the authority to influence the process of making and implementing political decisions. According to Almond [8], the forms of political participation are divided into two, namely conventional 
political participation and non-conventional political participation. The details of conventional and unconventional political participation forms are:

a) Conventional political participation

- Voting or voting

- Political discussion

- Campaign activities

- Form and join interest groups

- Individual communication with political or administrative officials

b) Unconventional political participation

- Submitting a petition

- Demonstrate

- Confrontation

- Strike

- Acts of political violence against property: destruction, bombing, arson

- Acts of political violence against humans: kidnapping, murder, guerrilla war strategy, revolution.

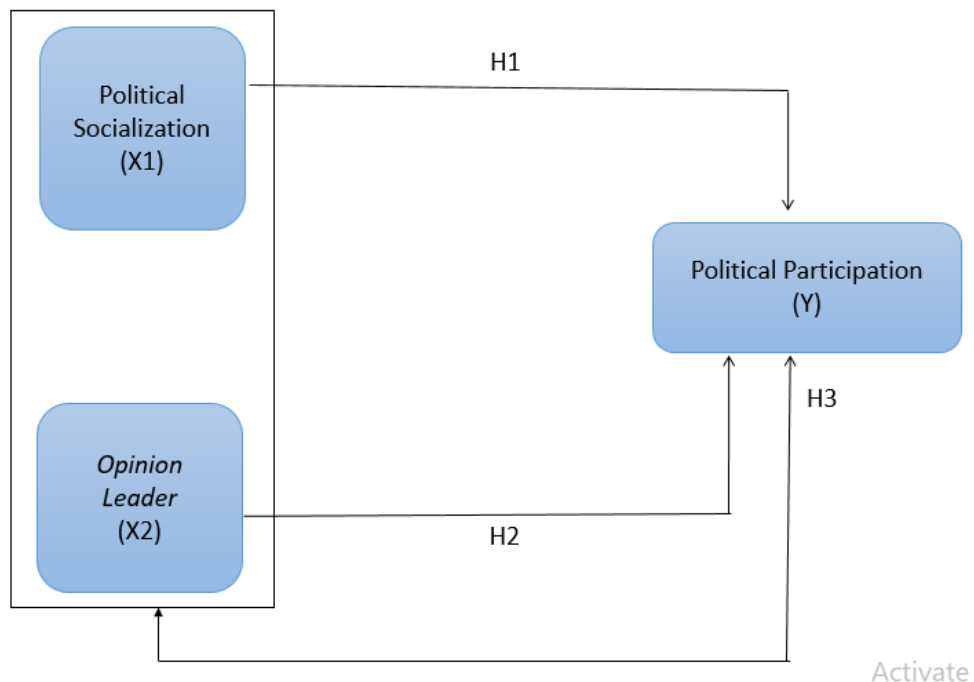

Fig. 1. Framework for Thinking Involving Political Socialization of Election Organizers through Leaders' Opinions on Political Participation.

\section{Hypothesis}

According to Sugiyono [9], hypothesis can be defined as a temporary answer to the research problem formulation. The hypothesis in this study were as followed:

$\mathrm{H}_{1}$ : There is an influence of political socialization on the communities' participation in the border region of the Republic of Indonesia-Timor Leste, Raihat District, NTT in the 2019 Elections. 
$\mathrm{H}_{2}$ : There is an influence of opinion leaders on the communities' participation in the border region of the Republic of Indonesia-Timor Leste, Raihat District, NTT in the 2019 Elections

$\mathrm{H}_{3}$ : There is an influence of political socialization and opinion leaders on the communities' participation in the border region of the Republic of Indonesia-Timor Leste, Raihat District, NTT in the 2019 Elections.

\section{Research Methods}

This research was conducted in the District of Raihat-NTT bordering Timor Leste. This research used quantitative research methods which could also be interpreted as a research method based on the philosophy of positivism used to examine specific populations or samples. Data collection was by using research instruments with quantitative or statistical data analysis with the aim to test the hypotheses that had been set. This method is called positivistic method because it is based on the philosophy of positivism and a part of the sociopsychological tradition in which the researchers would analyze the cause-effect relationship that would predicted the effect of communication. This tradition put the attention on persuasion and attitude changes in processing messages. From this point, it would show how the opinion leader bridged the political socialization of election administration to be implemented in order to create participation.

This study had three variables: variable X1 was Political Socialization, variable X2 was opinion leader and variable $\mathrm{Y}$ was political participation of the Border Society. As for the total population of 1013 voters, the minimum number of samples was drawn based on random sampling with a total of 287. This study used Likert scale. In general, respondents' answers were measured by using Likert scale by doing scoring through numerical values for example $1,2,3,4$, and 5. In analyzing the data obtained in order to test hypotheses, the authors used parametric statistics. The technique used to test hypotheses was product moment correlation, partial correlation analysis, multiple regression, and determination.

\section{Findings and Discussion}

The regression coefficient of political socialization (X1) was 0.250 . It indicated political socialization only gave the least influence on political participation. The positive symbol of regression coefficient indicated political socialization has a direct effect on political participation, which meant any increase in political socialization would cause an increase in political participation. T value was 4.376 with a significance of intrinsic motivation $t$ of 0,000 $<0.05$, with a very strong correlation of SC $\beta 1(0.205)$. Thus, it gave evident that the variable of political socialization (X1) had a significant effect on political participation (Y). Thus, the first hypothesis can be accepted.

Opinion leaders' regression coefficient (X2) of 0.457 showed the magnitude of opinion leaders' influence on political participation. A positive symbol of regression coefficient indicated opinion leaders had a direct effect on political participation, which meant that any increase in opinion leaders will cause an increase in political participation. $\mathrm{T}$ value was of 12.533 with a significance of intrinsic motivation t of $0,000<0.05$ and with a fairly strong correlation of SC $\beta 2$ (0.586). 


\begin{tabular}{|c|c|c|c|c|c|c|}
\hline \multicolumn{7}{|c|}{ Coefficients' } \\
\hline \multirow{2}{*}{\multicolumn{2}{|c|}{ Model }} & \multicolumn{2}{|c|}{$\begin{array}{l}\text { Unstandardized } \\
\text { Coefficients }\end{array}$} & \multirow{2}{*}{$\begin{array}{c}\text { Standardized } \\
\text { Coefficients } \\
\text { Beta }\end{array}$} & \multirow{2}{*}{$\mathrm{t}$} & \multirow{2}{*}{ Sig. } \\
\hline & & $\mathrm{B}$ & Std. Error & & & \\
\hline \multirow{3}{*}{\multicolumn{2}{|c|}{$1 \mid \begin{array}{l}\text { (Constant) } \\
\text { Political } \\
\text { Socialization } \\
\text { Opinion } \\
\text { Leader }\end{array}$}} & 9.464 & 2.024 & & 4.676 & .000 \\
\hline & & .250 & .057 & 205 & 4.376 & .000 \\
\hline & & .457 & .036 & .586 & 12.533 & .000 \\
\hline
\end{tabular}

a. Dependent Variable: Political Socialization

Therefore, it is proven that political participation variable (X2) significantly influences political participation (Y). Based on this result, the second hypothesis can be accepted. From the Anova Test or the F test, the F count was 134,094 with a significant level of 0,000 . Because the significance of 0.000 was less than 0.05 , it could be said that political socialization through opinion leaders jointly influenced political participation. Thus, the fourth hypothesis is statistically accepted.

Model Summary ${ }^{\mathrm{b}}$

\begin{tabular}{|c|c|c|c|c|}
\hline Model & $\mathrm{R}$ & $\mathrm{R}$ Square & $\begin{array}{c}\text { Adjusted R } \\
\text { Square }\end{array}$ & $\begin{array}{c}\text { Std. Error of the } \\
\text { Estimate }\end{array}$ \\
\hline 1 & $.697^{\mathrm{a}}$ & .486 & .482 & 4.256 \\
\hline
\end{tabular}

a. Predictors: (Constant), Opinion Leader, Political Socialization.

b. Dependent Variable: Political Participation.

The correlation coefficient test $(\mathrm{R})$ between variable $\mathrm{X} 1$ and $\mathrm{X} 2$ with variable $\mathrm{Y}$ was 0.697 , the $\mathrm{R}^{2}$ variables for political participation were explained by political socialization and opinion leader variables $48.6 \%$, and the remaining $51.4 \%$ was explained by other variables not included in this model (not being researched).

\subsection{Effects of Political Socialization on Political Participation}

The results of research that had been done showed that political socialization had a significant influence on political participation. The role of political socialization, as a process of forming political attitudes and orientation to members of the community, has a political socialization process that lasts for quite a long time resulted from the interplay of individual personalities with relevant political experiences that gives shape to their political behavior. Knowledge, values, and attitudes acquired by a person form a perception through individuals in accepting political stimuli. Political socialization encourages citizens to prioritize voting rights, fosters concern for the region, and creates good nationalism of this nation and state, Indonesia. The results of this study are also supported by Lisa Apriani's study (2015) which states that political socialization has a significant positive effect on political participation.

Descriptively viewed, the Raihat, NTT sub-district, respondents indicated that the message in political socialization was able to provide an attitude of awareness on the importance of political participation to the community and was developing well but the community's knowledge still lack on political socialization. It was seen by the condition where there were still many people who did not understand information about how their votes were counted. Whereas, political socialization influenced the community to be able to participate in 
politics so that election organizers must pay attention to what is the right step to respond to the problem. The results of this study were in accordance with the real conditions even when political participation was claimed to be fulfilled. However, there was a decrease in the number of political participations even though the government had given voting rights to its citizens properly. With political socialization, it is hoped that political participation will increase community's participation so that the purpose of the democratic party can be realized.

\subsection{The Influence of Opinion Leaders on Political Participation}

Convincing rural communities certainly requires someone who can be trusted on developing development issues. One political actor who has good credibility becomes opinion leader in informing rural communities about regional development. This research proved opinion leaders had a positive and significant influence on political participation in Raihat District, NTT. Indeed, opinion leaders are expected to have a positive impact on increasing political participation. In accordance with the results of the study, in his discussion, Gledis [10] states that opinion leaders influence political participation. A good opinion leader will bring a better image. This research is also supported by Shachar and Nalebuff [11] whom states that opinion leaders influence political participation. Opinion leaders are considered as an opportunity to provide satisfaction in the long run.

Field analysis results showed that opinion leader figures in Raihat had been doing their roles pretty well. In the implementation of the voting process, everything had gone in an orderly manner because opinion leaders had been able to establish good relations with the community of Raihat sub-district. On the other hand, the community was still not satisfied with opinion leaders who had not prioritized the interests of elections for village development. It was seen that the community still lack in-depth information about the 2019 elections. Functioning as a bridge for any information that enters Raihat sub-district, opinion leaders must be able to have good communication because all information obtained must be filtered before being distributed to the public.

In addition, there were still some opinion leaders who had not been able to accommodate every aspiration of the community. It could be seen from how big the gap was between the government's needs and the village head's expectations. One way to solve it is can be done by synchronizing the aim of the party's vision and mission itself. Its purpose is to make opinion leaders be adjusted to the conditions in every region and also to be indirectly able to avoid the ineffectiveness in language content and information inefficiency in political participation itself. These conditions were shown by citizens who got their rights to vote but were not widely applied in democratic life, and there were still many people who lack initiative, and very low level of understanding. It is hoped that opinion leaders will be more focused and more appropriate to help the community in Raihat District. With overflowing information and an active role in the sub-district, citizens will automatically increase their awareness to participate effectively in politics and can contribute optimally expecting to have a good impact on the development of the region.

\subsection{The Effect of Simultaneous Political Socialization and Opinion Leaders on Political Participation}

The results of the research conducted showed that simultaneous political socialization and opinion leaders had a significant effect on political participation in Raihat sub-district, NTT. This result produces feedback to the General Election Commission (KPU). The more people 
are involved, the more influential it will be on the results of political participation, which is required to provide a link in providing political education to the community through opinion leaders regarding information, procedures and other attitudes. It can be served by providing committees and real programs that are viable and sustainable so that the community is more reactive and active in accordance with the ideals of one nation and state.

In the end, these all lead to policies and responsibilities to improve the quality of local community. In addition, certain support of unlimited human resources is also necessary and it will optimally affect the incoming information to the community in Raihat sub-district.

\section{Conclusion}

Based on the results of research and discussion, three conclusions can be drawn as follow:

a) There is a significant influence of political socialization to political participation in Raihat-NTT District. The results of the $\mathrm{t}$ test between political socialization and political participation obtained a Sig value of 0,000 in which the value was smaller than the significance value used in this study, which is 0.05 . It means that $\mathrm{H}_{0}$ is rejected and $\mathrm{H}_{1}$ is accepted. This result described that political socialization had a significant effect on political participation with Beta value of 0.205. It showed a direct relationship of the two variables.

b) There is a significant influence of opinion leaders to political participation in the District of Raihat, NTT. Opinion leaders has an effect on political participation. T test results of opinion leaders' impact on political participation obtained a Sig 0,000 value where the value was smaller than the significance value in this study that was 0.05 . It means that $\mathrm{H}_{0}$ is rejected and $\mathrm{H}_{1}$ is accepted. This showed opinion leaders had a significant effect on political participation with a Beta value of 0.586 and it also showed a direct relationship between the two variables or the opposite of the two variables.

c) There is a significant influence of political socialization and opinion leaders to political participation in Raihat District - NTT. The test results $f$ presented significance value of 0,000 . Since the Sig value was above 0.05 , it could be said that the two independent variables simultaneously influenced political participation. For testing by using $\mathrm{F}$ Test, F count value was of 134,094 and F Table was 2.636 which meant that from the results, $F$ count $>F$ Table. It means that $\mathrm{H}_{0}$ is rejected and $\mathrm{H}_{1}$ is accepted. It can be concluded that there was a simultaneous influence of political socialization and opinion leaders to the political participation of Raihat District, Atumbua - NTT.

\section{Suggestion}

a) For the Government

Based on the results of the research, discussion, and conclusions obtained, the suggestions that can be given are as follows: First, local governments are advised to pay attention to political socialization that can increase awareness of ownership and generate positive reactions according to their voting rights by holding democratic parties with opinion leaders tha are expected to increase. Second, election 
administrators are advised to pay attention to opinion leaders who help citizens overcome the problem of democracy, increase the role of the community and start exercising their voting rights and increase awareness and curiosity of the people in Raihat District. It's hoped that local residents are able to vote according to the time set by the general election in the future. Third, the government is advised to pay attention to the political participation of the sub-district residents in Raihat, NTT. The government is also expected to listen to their aspirations so that the citizens in Raihat will also feel they are Indonesian people who are recognized for their existence in Indonesia and respected in accordance to their human rights. Fourth, the Republic of Indonesia's government is advised to pay attention to the political participation of the people in Raihat, NTT sub-district, to find out the positive results of regionalism which are expected to emancipate every citizen to be able to make political contributions and the best voting results for Indonesia.

b) For Further Researchers

The next researcher can develop this research as follows:

- Use other methods in examining the effect of political socialization through opinion leaders to the political participation of borderline communities in Raihat District, NTT. For example, the next one can study the topic by using qualitative approach so that information and data obtained are more comprehensive.

- Develop a research model by having more varied population and sample so that it can be a useful input for the government.

- Explore the influence of independent variables on political participation, and involve other variables such as: political education, campaign strategies, and/or political communication in effective political communication to predict political participation.

\section{References}

[1] G. Weimann, D. H. Tustin, D. Van Vuuren, and J. P. R. Joubert, "Looking for opinion leaders: Traditional vs. modern measures in traditional societies," Int. J. Public Opin. Res., vol. 19, no. 2, pp. 173-190, 2007.

[2] P. F. Lazarsfeld, B. Berelson, and H. Gaudet, "The people's choice," 1944.

[3] Efriza, Political Explore: Sebuah Kajian Ilmu Politik. Bandung: Alfabeta, 2012.

[4] P. Kotler, Manajemen Pemasaran. Edisi Mileinium. Jakarta: PT. Indeks Kelompok Gramedia, 2000.

[5] C. C. Windham, "The Impact of Organizational Source Credibility and the Factors that Contribute to Opinion Leaders' Decisions to Diffuse Information.” University of Florida, 2009.

[6] G. Yuki, Leadership In Organization. New Jersey: Prentice hall, 2001.

[7] R. Surbakti, "Memahami Ilmu Politik, Jakarta," PT Gramedia Widiasarana Indones., 2010.

[8] M. Mas' oed, "Untuk Apa Negara? Renungan Akhir Tahun tentang Tanggung Jawab Penyelenggaraan Layanan Publik," text, 2011.

[9] Sugiyono, Metode Penelitian Kuantitatif, Kualitatif dan R\&D. Penerbit Alfabeta Bandung, 2010.

[10] G. J. Manopo, "Peranan Opinion Leader dalam Meningkatkan Partisipasi Masyarakat untuk Menunjang Program Bersih Eceng Gondok Danau Tondano," ACTA DIURNA Komun., vol. 2, no. 1, 2013.

[11] R. Shachar and B. Nalebuff, "Follow the leader: Theory and evidence on political participation," Am. Econ. Rev., vol. 89, no. 3, pp. 525-547, 1999. 